\title{
ANTIBACTERIAL ACTIVITY, CHEMICAL COMPOSITION, AND CYTOTOXICITY OF LEAF'S ESSENTIAL OIL FROM BRAZILIAN PEPPER TREE (SCHINUS TEREBINTHIFOLIUS, RADDI)
}

\author{
A.B. Silva ${ }^{1}$, T. Silva ${ }^{1}$, E.S. Franco ${ }^{2}$, S.A. Rabelo ${ }^{2}$, E.R. Lima ${ }^{2}$, R.A. Mota $^{2}$, C.A.G. da Câmara ${ }^{3}$, N.T. Pontes-Filho ${ }^{4}$, J.V. \\ Lima-Filho $^{1 *}$
}

\begin{abstract}
${ }^{1}$ Departamento de Biologia, Universidade Federal Rural de Pernambuco, Recife, PE, Brasil; ${ }^{2}$ Departamento de Medicina Veterinária, Universidade Federal Rural de Pernambuco, Recife, PE, Brasil; ${ }^{3}$ Departamento de Química, Universidade Federal Rural de Pernambuco, Recife, PE, Brasil; ${ }^{4}$ Departamento de Patologia, Universidade Federal de Pernambuco, Recife, PE, Brasil.
\end{abstract}

Submitted: March 13, 2009; Returned to authors for corrections: April 27, 2009; Approved: August 23, 2009.

\begin{abstract}
The antibacterial potential of leaf's essential oil (EO) from Brazilian pepper tree (Schinus terebinthifolius Raddi) against staphylococcal isolates from dogs with otitis externa was evaluated. The minimum inhibitory concentration of EO ranged from 78.1 to $1,250 \mu \mathrm{g} / \mathrm{mL}$. The oil was analyzed by GC and GC/MS and cytotoxicity tests were carried out with laboratory animals.
\end{abstract}

Key words: Essential oil; Brazilian pepper tree; Schinus terebinthifolius, otitis externa; Staphylococcus.

Essential oils act against microorganisms by causing instability of the plasma membrane leading to rupture of cells (2). This effect is due to array of antimicrobial compounds in oils that are from (but not limited to) terpinoid class as thymol and carvacrol (1). Although antimicrobial activity can be enhanced by a single chemical compound, it usually seems a result of the synergy among many chemical compounds present in oils. For instance, Sonboli et al. (2006) described antimicrobial activity in essential oils from Salvia species were remarkably dependent of synergy between linalool, 1,8-cineol, alpha-pinene, beta-pinene, beta-caryophyllene and limonene (22). In addition, the range of antimicrobial activity can vary with bacterial species involved. Cristani et al. (2007), using a biomembrane model to study essential oil's action mechanism, showed thymol was more toxic against $S$. aureus than carvacrol, p-cymene, and gamma-terpinene, while carvacrol and p-cymene were mainly inhibitory against E. coli (5).
The Brazilian pepper tree or Aroeira (Schinus terebinthifolius Raddi, Anacardiaceae) is broadly found in Northeast region of Brazil and has been used in popular medicine to treat respiratory infections (12). Previously, Siddiqui et al. (21) reported essential oils of this plant carry antibacterial activity against Escherichia coli, Shigella dysenteriae, Bacillus subtilis and Staphylococcus albuns. Ancient phytochemical studies revealed the presence of triterpene alcohols, ketones, acids, monoterpenes and sesquiterpenes in the bark, leaves and fruits (13). Moreover, a number of studies with leaf's essential oil of plants collected at different regions of the globe have shown distinct chemotypes by GC/MS analyses, and prevalence of distinct chemical compounds. For example, $\alpha$-pinene $(51,82 \%)$ in Indian plants (3), $\alpha$-phellandrene $(24,2 \%)$ in Egypt plants (8), limonene $(17,7 \%)$ and p-cymene $(15,7 \%)$ in Reunion Island plants (24).

The veterinary use of essential oils depends on clinical

\footnotetext{
*Corresponding Author. Mailing address: Laboratório de Microbiologia e Imunologia, Departamento de Biologia, Universidade Federal Rural de Pernambuco, R. Dom Manoel de Medeiros s/n, Campus Dois Irmãos, Recife, Pernambuco, CEP 52171-900, Brasil.; Tel: + 5531813320.6312 Fax: + 55 31 81 3320.6300.; Email: jvitor@db.ufrpe.br
} 
trials and has been fewer exploited in therapeutics, such as herbal cream containing tea tree oil that was successfully used on symptomatic treatment of canine dermatitis (20). Besides, antimicrobial combinations like chlorhexidine digluconate and tea tree oil or eucalyptus oil and thymol, were useful against biofilm cultures of bacterial isolates of $S$. epidermidis (9). Altogether, in the present study leaf's essential oil from Brazilian pepper tree was evaluated against clinical isolates of coagulase-positive Staphylococcus ssp. from dogs with otitis externa. This essential oil was chemically evaluated by GC and GC/MS analyses and acute toxicity assays were performed using laboratory animals.

Brazilian pepper tree (Schinus terebinthifolius Raddi) was collected at North-East Brazil (800 52.79" latitude S, $34^{\circ} 5700.81$ " longitude W). The voucher species was deposited at the Vasconcelos Sobrinho Herbarium of the university and numbered as 42544. Fresh leaves were submitted to water distillation for $2 \mathrm{~h}$ and collected by a Clevenger-type apparatus. The essential oil (EO) was separated from water, dried with $\mathrm{Na}_{2} \mathrm{SO}_{4}$ and stored in sealed vials at low temperature. GC and GC/MS analysis was carried out as described by Pontes et al. (19).

Staphylococci $(n=9)$ isolates were obtained from the exudates of the ear canals of otopatic dogs being treated at the UFRPE Veterinary Clinic. Identification of isolates used the APIStaph Kit (Biomerieux) and antibiogram susceptibility tests were conducted following CLSI instructions (formally, Committee for Clinical Laboratory Standards) (17). The EO antimicrobial assays were initially carried out by the agar-well diffusion method (18). Staphylococci isolates were cultured in the dishes $\left(10^{8}\right.$ cells $/ \mathrm{mL}-0.5$ of the MacFarland standard) and wells were topped up with $20 \mu \mathrm{L}$ of essential oil at concentration of $100,50,25$ and $12.5 \mathrm{mg} / \mathrm{mL}$ (w/v) in DMSO (Dimetil Sulfoxide). Such results were expressed as mean \pm SD of the growth inhibition zone in millimeters. Differences between inhibition zones (mean $\pm \mathrm{SD}$ ) produced by distinct dosages of the EO were compared by Student t test or ANOVA with $\mathrm{P}<0.05$. The minimum inhibitory $(\mathrm{MIC})$ concentration was performed using the broth dilution method in concentrations ranging from 36 to $2500 \mu \mathrm{g} / \mathrm{mL}$ (10). The MIC was the lowest oil concentration that caused visible inhibition growth; minimum bactericidal concentration (MBC) was the lowest concentration resulting in no growth after the incubation period time of $24 \mathrm{~h}$ at $37^{\circ} \mathrm{C}$. All assays were performed in duplicate.

Male Swiss mice with approximately $35 \mathrm{~g}$ in weight were used for acute toxicity tests, following institutional rules stated by the Animal Ethics Committee of the UFRPE. An aliquot of the EO previously dissolved in DMSO was diluted in Tween $803 \%(\mathrm{v} / \mathrm{v}$ in Phosphate saline) to produce stock concentrations of $100,225,300,375,500$ and $1000 \mathrm{mg} / \mathrm{kg}$. Then $0.2 \mathrm{~mL}$ was administered intraperitoneally to adult Swiss mice (6 animals per group for each dosage). Control animals received only the solvent devoid of essential oil. At the end of experiments the survival animals were sacrificed by anesthesia with Halothane (Halocarbon Laboratories, USA) and submitted to histological examination.

Otitis externa in dogs is caused by multiple factors such as changes in temperature and humidity of the ear canal, accidents with perforating objects, host immunity and infection. The disease therapeutics have been particularly intended to eliminate opportunistic microorganisms that proliferate in the ear canal of healthy as well as otopatic dogs, such as Staphylococcus intermedius, Streptococcus canis, Escherichia coli, Proteus sp. and the yeast Malassezia pachydermatis (14). In spite of the changes in number and species type of isolates, Staphylococcus intermedius have been especially associated with disease and targeted by antibiotic therapy (11). Besides, methicillin-resistant $S$. intermedius (MRSI) and methicillinresistant $S$. schleiferi (MRSS) were significantly more common in dogs than in cats (16).

In the present study, S. intermedius (eight isolates - LMIS2 to LMI-S9) and S. schleiferi (one isolate - LMI-S1) were identified in the ear canal of dogs. The isolate LMI-S8 was resistant to tetracycline, ciprofloxacin, and erythromycin, whereas LMI-S9 was resistant to penicillin, tetracycline, erythromycin and gentamicin. The remaining bacterial isolates were sensitive to all antibiotics. Also, all isolates were sensitive 
Silva, A.B. et al.

to oxacilin suggesting the lack of Meticilin-resistant strains. This preliminary assay was useful to typify staphylococcal antibiotic profiles prior to carry out assays with EO from Brazilian pepper tree. The agar-well diffusion technique has shown growth inhibition zones of the EO against staphylococcal isolates until the lower assayed concentration of
$12.5 \mathrm{mg} / \mathrm{mL}$ (Mean: $7.7 \mathrm{~mm} \pm 0.61$ ). Besides this, a statistical significance was observed among the dosages tested (Table 1). The MIC ranged from 78.1 to $1,250 \mu \mathrm{g} / \mathrm{mL}$ but the oil was not bactericidal to majority of bacterial isolates, except by isolate LMI-S9, which showed MBC corresponding to the higher tested dosage of $2,500 \mu \mathrm{g} / \mathrm{mL}$.

Table 1. Antibacterial activity of leafs' essential oil from Brazilian pepper tree.

\begin{tabular}{|c|c|c|c|c|c|c|}
\hline \multirow{2}{*}{$\begin{array}{l}\text { Staphylococci } \\
\text { isolates }\end{array}$} & \multicolumn{4}{|c|}{ Growth inhibition zones in millimeters $($ mean \pm SD) } & \multicolumn{2}{|c|}{$\mu \mathrm{g} / \mathbf{m L} * *$} \\
\hline & $100 \mathrm{mg} / \mathrm{mL}$ & $50 \mathrm{mg} / \mathrm{mL}$ & $25 \mathrm{mg} / \mathrm{mL}$ & $12.5 \mathrm{mg} / \mathrm{mL}$ & MIC & MBC \\
\hline LMI-S1 & $17 \pm 1.0$ & $9 \pm 1.0$ & $8 \pm 1.0$ & $8 \pm 0.5$ & 156.2 & - \\
\hline LMI-S2 & $17 \pm 1.0$ & $11 \pm 1.0$ & $9 \pm 1.0$ & $8 \pm 0.5$ & 625 & - \\
\hline LMI-S3 & $11 \pm 0.5$ & $10 \pm 0.5$ & $8.5 \pm 1.0$ & $8.5 \pm 0.5$ & 625 & - \\
\hline LMI-S4 & $11 \pm 1.0$ & $11 \pm 0.5$ & $9 \pm 0.5$ & $8 \pm 1.0$ & 1250 & - \\
\hline LMI-S5 & $16.5 \pm 0.5$ & $10 \pm 0.5$ & $9 \pm 1.0$ & $7.5 \pm 0.5$ & 78.1 & - \\
\hline LMI-S6 & $15.5 \pm 0.5$ & $10 \pm 0.5$ & $8 \pm 0.5$ & $7.5 \pm 0.5$ & 1250 & - \\
\hline LMI-S7 & $10.5 \pm 0.5$ & $10 \pm 0.5$ & $8 \pm 0.5$ & $6.5 \pm 0.5$ & 625 & - \\
\hline LMI-S8 & $17 \pm 1.0$ & $11 \pm 1.0$ & $10 \pm 0.5$ & $8 \pm 0.5$ & 312.5 & - \\
\hline LMI-S9 & $12 \pm 0.5$ & $11 \pm 0.5$ & $9 \pm 0.5$ & $7 \pm 0.5$ & 312.5 & 2,500 \\
\hline Mean $\pm \mathrm{SD}^{*}$ & $14.6 \pm 2.88^{\mathrm{a}}$ & $10.3 \pm 0.7^{\mathrm{b}}$ & $8.7 \pm 0.66^{\mathrm{c}}$ & $7.7 \pm 0.61^{\mathrm{d}}$ & - & - \\
\hline
\end{tabular}

The current protocol for control of bacterial infection in otitis externa episodes uses gentamicin administered topically against most of staphylococci isolates and amoxicillinclavulanic acid for the remaining bacterial species (14). However, an emergence of bacterial isolates carrying mecA gene has been reported for $S$. hominis, $S$. aureus, $S$. epidermidis, S. haemolyticus and S. warneri in cats and dogs (15). Our data have shown EO from Brazilian pepper tree was active against all coagulase-positive staphylococci obtained from diseased dogs, some resistant to several antibiotics indicated for therapy. Nevertheless, the lack of in vivo pharmacokinetic studies became unfeasible to preview its antimicrobial effects in animal therapeutics. Thus, due to nonbactericidal effect of this oil, it seems to be more appropriated for inclusion in topic preparations or antimicrobial combinations.

In spite of essential oils' bioactive compounds can modify proportionally interfering on antimicrobial ability, GC and GC/MS analyses revealed thirty-three components were identified, representing $95.5 \%$ of EO from leaf of the Brazilian pepper tree (Table 2). The main components were p-cymen-7ol (22.5\%); 9-epi-(E)-cariophyllene (10.1\%), carvone $(7.5 \%)$ and verbenone $(7.4 \%)$. From these p-cymen and caryophyllene were previously reported by its inhibitory effect on microorganisms $(4,6)$. These findings highlight the importance to elucidate the chemical composition of plant essential oils from distinct geographic regions. 
Table 2. Chemical compounds in leaf's essential oil from Brazilian pepper tree.

\begin{tabular}{|c|c|c|}
\hline Compounds & $\mathbf{R I}^{\mathbf{a}}$ & $\%^{b}$ \\
\hline$o$-Cymene & 1022 & 1,7 \\
\hline Limonene & 1031 & 0,2 \\
\hline$m$-Cymenene & 1082 & 0,7 \\
\hline 2,5-Dimethyl styrene & 1096 & 1,0 \\
\hline Perillene & 1099 & 0,5 \\
\hline Myrcenol & 1118 & 0,8 \\
\hline$\alpha$-Campholenal & 1125 & 0,8 \\
\hline trans-Limonene oxide & 1139 & 3,1 \\
\hline cis-Verbenol & 1140 & 0,9 \\
\hline trans-Verbenol & 1144 & 2,7 \\
\hline$m$-Cymen $-8-\mathrm{ol}$ & 1180 & 4,1 \\
\hline p-Cymen-8-ol- & 1183 & 3,2 \\
\hline$\alpha$-terpineol & 1189 & 0,7 \\
\hline Verbenone & 1204 & 7,4 \\
\hline Carvone & 1242 & 7,5 \\
\hline$\alpha$-Terpinen -7-al & 1282 & 1,9 \\
\hline p-Cymen-7-ol & 1287 & 22,5 \\
\hline$\beta$-dehydro-Eelsholtzione & 1298 & 4,6 \\
\hline$\alpha$-Cubebene & 1351 & 0,3 \\
\hline neo-dihidro Carveol acetato & 1356 & 0,5 \\
\hline$\beta$-Bourbonene & 1384 & 0,1 \\
\hline iso-Longifolene & 1402 & 2,7 \\
\hline cis-Muurola-4(14),5-diene & 1460 & 3,5 \\
\hline 9-epi-(E)-caryophyllene & 1467 & 10,1 \\
\hline$\beta$-Chamigrene & 1475 & 1,0 \\
\hline$\gamma$-Himachalene & 1476 & 0,9 \\
\hline$\gamma$-Muurolene & 1477 & 1,8 \\
\hline$\alpha$-Bulnesene & 1507 & 0,6 \\
\hline Spathulenol & 1576 & 0,6 \\
\hline Caryophyllene oxide & 1581 & 5,2 \\
\hline$\beta$-Eudesmol & 1649 & 1,0 \\
\hline$\alpha$-Cadinol & 1653 & 0,6 \\
\hline Aristolone & 1756 & 2,3 \\
\hline
\end{tabular}

${ }^{a}$ RI, Retention Index.

$\mathrm{b}(\%)$, relative percentage obtained from peak area.

Previously stem bark extracts of the Brazilian pepper tree were reported to produce DNA damage and mutation in bacteria (7). Such toxic effects have been specially evidenced in flavonoid-enriched fractions (23). On the other hand, we were not aware from previous reports describing in vivo cytotoxicity for leaf's essential oil of this plant. In view of toxicological analyses are first step prior clinical trials, we carried out a preliminary evaluation of EO from Brazilian pepper tree. The observation of animal clinical signs after inoculums and histological examination supported the oil was not remarkably toxic. There was no evidence of changes in behavior pattern throughout $24 \mathrm{~h}$ observation at dosages smaller than $225 \mathrm{mg} / \mathrm{Kg}$. The histological examination showed that coagulative necrosis in kidneys and cell vacuolization plus hyperemia in the liver was limited to dosages higher than 100 $\mathrm{mg} / \mathrm{Kg}$ (data not shown). Taken together, we conclude the lower toxicity and potent antimicrobial activity of EO from Brazilian pepper tree sustain its potential use for veterinary 
Silva, A.B. et al.

practices.

\section{ACKNOWLEDGEMENTS}

The authors thank MSc. Maria Helena for provide animals used in this study, and Dra. Carmen Zickel for botanic identification of Brazilian Pepper Tree. The authors also thank the Brazilian Council of Research (CNPq) by research funding. Prof. Lima-Filho was supported by a Scholarship funding from Programa de Educação Tutorial (PET-MEC/SESu).

\section{REFERENCES}

1. Botelho, M.A.; Nogueira, N.A.; Bastos, G.M.; Fonseca, S.G.; Lemos, T.L.; Matos, F.J.; Montenegro, D.; Heukelbach, J.; Rao, V.S.; Brito, G.A. (2007). Antimicrobial activity of the essential oil from Lippia sidoides, carvacrol and thymol against oral pathogens. Braz J Med Biol Res 40: 349-356.

2. Burt, S. (2004). Essential oils: their antibacterial properties and potential applications in foods-a review. Int J Food Microbiol 94: 223-253.

3. Chowdhury, A.R.; Tripani, S. (2001). Essential oil from leaves of Schinus terenbinthifolius Raddi. Ind. Perfumer 45: 257-259.

4. Cox, S.D.; Mann, C.M.; Markham, J.L. (2001). Interactions between components of the essential oil of Melaleuca alternifolia. J Appl Microbiol 91: 492-497.

5. Cristani, M.; D'Arrigo, M.; Mandalari, G.; Castelli, F.; Sarpietro, M.G.; Micieli, D.; Venuti, V.; Bisignano, G.; Saija, A.; Trombetta, D. (2007). Interaction of four monoterpenes contained in essential oils with model membranes: implications for their antibacterial activity. J Agric Food Chem 55: 6300-6308.

6. Cunico, M.M.; Lopes, A.R.; Côcco, L.C.; Yamamoto, C.I.; Plocharski, R.C.; Miguel, M.D.; Junior, A.D.; Auer, C.G.; Miguel, O.G. (2007). Phytochemical and antibacterial evaluation of essential oils from Ottonia martiana miq. (Piperaceae) J Braz Chem Soc 18, doi: 10.1590/S010350532007000100021

7. de Carvalho, M.C.; Barca, F.N.; Agnez-Lima, L.F.; de Medeiros, S.R. (2003). Evaluation of mutagenic activity in an extract of pepper tree stem bark (Schinus terebinthifolius Raddi). Environ Mol Mutagen 42: 185191.

8. Ibrahim, M.; Fobbe, R.; Nolte, J. (2004). Chemical composition and biological studies of Egyptian Schinus molle L. and Schinus terebinthifolius raddi oils. Bull Fac Pharm 42: 289-296.

9. Karpanen, T.J.; Worthington, T.; Hendry, E.R.; Conway, B.R.; Lambert, P.A. (2008). Antimicrobial efficacy of chlorhexidine digluconate alone and in combination with eucalyptus oil, tea tree oil and thymol against planktonic and biofilm cultures of Staphylococcus epidermidis. J Antimicrob Chemother 62(5): 1031-1036.
10. Koneman, E.W.; Allen, S.D.; Janda, W.M.; Schreckenberger, M.P.; Winn Jr., W.C. (2001). Diagnóstico Microbiológico - Texto e Atlas Colorido, 5a Ed. MEDSI, São Paulo-Brasil.

11. Lilenbaum, W.; Veras, M.; Blum, E.; Souza, G.N. (2000). Antimicrobial susceptibility of Staphylococci isolated from otitis externa in dogs. Lett Appl Microbiol 31: 42-45.

12. Lima, M.R.F.; Lunaa, J.S.; Santos, A.F.; Andrade, M.C.; Santana, A.E.; Genet, J.P.; Márquez, B.; Neuville, L.; Moreau, N. (2006). Anti-bacterial activity of some Brazilian medicinal plants. J Ethnopharmacol 105: 137147.

13. Lloyd, H.A.; Jaouni, T.M.; Evans, S.L.; Morton, J.F. (1977). Terpenes of Schinus terebinthifolius. Phytochem 16: 1301-1302.

14. Lyskova, P.; Vydrzalova, M.; Mazurova, J. (2007). Identification and antimicrobial susceptibility of bacteria and yeasts isolated from healthy dogs with otitis externa. $J$ Vet Med 54: 559-563.

15. Malik, S.; Coombs, G.W.; O’Brien, F.G.; Peng, H.; Barton, M.D. (2006). Molecular typing of methicillin-resistant staphylococci isolated from cats and dogs. J Antimicrob Chemother 58: 428-31.

16. Morris, D.O.; Rook, K.A.; Shofer, F.S.; Rankin, S.C. (2006). Screening of Staphylococcus aureus, Staphylococcus intermedius, and Staphylococcus schleiferi isolates obtained from small companion animals for antimicrobial resistance: a retrospective review of 749 isolates (2003 4). Vet Dermatol 17: 332-337.

17. National Comitee for Clinical Laboratory Standards. (2002). Padronização dos Testes de Sensibilidade a Antimicrobianos por Discodifusão: Norma Aprovada M2-A8, Oitava Edição-Tradução ANVISA, Clinical and Laboratory Standards Institute, NCCLS, Villanova,PA, USA.

18. Perez, C.; Pauli, M.; Bazerque, P. (1990). An antibiotic assay by the agar-well diffusion method. Arch Biol Med Exp 15: 113-115.

19. Pontes, W.J.T.; Oliveira, J.C.S.; Câmara, C.A.G.; Lopes, A.C.H.; Gondim-Júnior, M.G.; Oliveira, J.V.; Schwartz, M.O.E. (2007). Composition and acaricidal activity of the Resin's essential oil of Protium bahianum Daly against two spotted spider mite (Tetranychus Urticae). J Essent Oil Res 19: 379-383

20. Reichling, J.; Fitzi, J.; Hellmann, K.; Wegener, T.; Bucher, S.; Saller, R. (2004) Topical tea tree oil effective in canine localised pruritic dermatitis--a multi-centre randomised double-blind controlled clinical trial in the veterinary practice. Dtsch Tierarztl Wochenschr 111(10): 408-414.

21. Siddiqui, R.R.; Zafar, U.; Chaudhry, S.S.; Ahmad, H. (1995). Antimicrobial activity of essential oils from Schinus terebinthifolius, Cypress sempervirens, Citrus limon, Ferula assafoetida. Part I. Pak J Sci Ind Res 38: 358-361.

22. Sonboli,A.;Babakhani,B.;Mehrabian,A.R.(2006).Antimicrobial activity of six constituents of essential oil from Salvia. Z Naturforsch 61: 160-164.

23. Varela-Barca, F.N.; Agnez-Lima, L.F.; de Medeiros, S.R. (2007). Base excision repair pathway is involved in the repair of lesions generated by 
Activity of essential oil from pepper tree

flavonoid-enriched fractions of pepper tree (Schinus terebinthifolius, Raddi) stem bark. Environ Mol Mutagen 48: 672-681.

24. Vernin, G.; Parkanyi, C. (2003). GC/MS analyses of the volatile constituents of Schinus terenbinthifolius from Reunion Island. Abstract of papers in: $225^{\text {th }}$ ACS National Meeting. Ed.: American Chemical Society, Washington D.C., USA. 